\title{
PELATIHAN LITERASI MEDIA MENGHADAPI ERA INDUSTRI 4.0 BAGI IBU RUMAH TANGGA DI DAERAH TANGERANG
}

Oleh :

\author{
Agustin Diana Wardhaningsih ${ }^{1}$, Sigit Pamungkas ${ }^{2}$ \\ Program Studi Ilmu Komunikasi -- Universitas Pelita Harapan ${ }^{1}$, \\ Program Studi Ilmu Komunikasi -- Universitas Pelita Harapan ${ }^{2}$ \\ agustin.wardhaningsih@uph.edu¹ , sigit.pamungkas@uph.edu²
}

\begin{abstract}
ABSTRAK
Kehadiran media sosial menjadi salah satu alat komunikasi yang mampu menembus ruang dan waktu. Kemudahan yang ditawarkan membuat media sosial menjadi salah satu referensi masyarakat untuk mengakses informasi atau berita dengan cepat. Dan terkadang informasi yang didapat positif dan mengandung kebenaran tetapi bisa saja informasi yang didapat merupakan berita bohong alias hoax. Perlu adanya literasi media sosial agar penggunaannya bukan mengarah ke hal yang negatif, tetapi menjadi positif dan bisa membangun kesejahteraan masyarakat.
\end{abstract}

Salah satu media sosial yang sangat tinggi penggunaannya di Indonesia adalah Whatsapp. Bukan hanya generasi muda saja yang menggunakannya tetapi juga orang tua, salah satu nya para ibu rumah tangga. Ibu rumah tangga wajib melek digital. Ibu rumah tangga harus mau belajar dan setidaknya mengetahui cara menggunakan media sosial secara positif. Dengan demikian peran ibu rumah tangga bisa aktif memberikan pengajaran kepada anak-anaknya sehingga mereka pun bisa menjadi generasi yang kreatif tidak hanya pasif menerima setiap informasi, tetapi bisa bijak menggunakan media sosial.

Kegiatan PKM ini bertujuan untuk memberikan pembelajaran kepada para ibu rumah tangga cara bijak bermedia sosial whatsapp. PKM ini dilakukan di dua lokasi di daerah Tangerang. PKM bagi ibu-ibu PKK kelurahan Bencongan Indah, Karawaci, dan juga bagi ibu-ibu rumah tangga di daerah Mauk, Tangerang.

Katakunci: Literasi Media, Media Sosial, Media Positif.

\section{PENDAHULUAN}

Perkembangan teknologi komunikasi yang sangat pesat hingga saat ini sudah sulit dipisahkan dari kehidupan masyarakat. Tingkat ketergantungan masyarakat dengan gadget, seperti smartphone semakin tinggi, terutama dalam mengakses media sosial. Selain digunakan sebagai alat berkomunikasi dengan berkirim pesan secara cepat, informasi apapun bisa didapat lewat media sosial. Berbeda dengan informasi yang kita dapatkan lewat media massa seperti koran, tv, maupun radio, informasi lewat media sosial belum tentu terbukti kebenarannya. Banyak berita hoax justru disebarkan melalui media sosial.

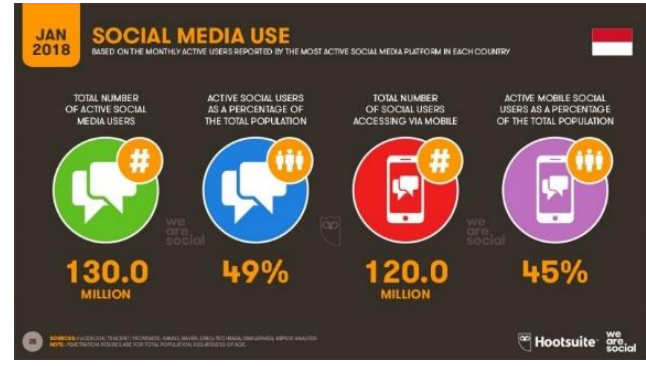

Gambar 1. Data Penggunaan Sosial Media di Indonesia tahun 2018

Sumber : Wearesocial.com.

Tingginya penggunaan media sosial di Indonesia seperti terlihat dari data websocial.com yang dikeluarkan tahun 
2018. 120 juta orang pengguna media sosial aktif lewat perangkat mobile. Kemudahan yang ditawarkan dalam mengakses, bisa dimana saja dan kapan saja membuat perangkat mobile banyak dipilih dibandingkan yang lain Salah satu pilihan adalah smartphone. Dengan harga yang beragam sehingga berbagai kalangan mudah membelinya. Penggunaan smartphone tidak hanya terbatas pada kalangan anak muda yang memang memiliki kemampuan beradaptasi sangat cepat dengan teknologi, namun juga para orang tua. Bahkan orang tua pun saat ini juga berusaha secara perlahan untuk mulai memanfaatkan media sosial untuk berkomunikasi.

Orang tua juga dituntut mengerti teknologi dan media sosial agar mampu mendampingi anak-anak dalam menggunakannya. Livingstone \& Helsper (2008) dalam Inasari (2017) menyebutkan orang tua dihadapkan pada tantangan akan dampak negatif media baru terhadap perilaku, sikap, dan keselamatan anak. Banyak sekali kasus yang menimpa anak-anak bahkan dari usia belia akibat kurang berhati-hati dalam menggunakan media sosial. Dari Cyber Bullying, konten pornografi, konten hoax, dan masih banyak lagi mudah diterima oleh anak yang sudah mengenal media sosial. Kecenderungan untuk popular, viral, dan terkenal, membuat anak-anak juga melakukan banyak cara tanpa mereka tahu apakah itu sesuatu yang baik atau tidak. Dari hasil survey yang dilakukan penulis pada PKM Pelatihan Pemanfaatan Instagram bagi Siswa SMAN 1 Tanjung Pandan Guna Meningkatkan Destination Awareness Pulau Belitung pada Juli 2018 pada sekitar 100 siswa SMA Tanjung Pandan Belitung, ditemukan fakta bahwa sebagian besar siswa akan mencari informasi dari media sosia (74\%). Hal tersebut karena kemudahan yang ditawarkan tanpa mereka mengerti apakah informasi yang didapat benar atau tidak.

Dari survey yang sama, selain mencari informasi lewat media sosial, maka anakanak juga akan bertanya kepada orang tua (64\%). Fakta ini menunjukkan bahwa orang tua masih dibutuhkan oleh anak untuk mendapatkan referensi yang benar dari setiap pertanyaan yang mereka ajukan. Sehingga setiap anak perlu mendapatkan pendampingan dan arahan dari sejak dini sehingga pada saat anak sudah mulai mengenal media baru, gadget, dan media sosial, anak telah teredukasi dengan baik sehingga menggunakannya secara positif.

Persoalan muncul saat banyak orang tua yang kurang mengerti dalam menggunakan gadget, malas untuk belajar, sehingga cenderung mengabaikan dan tidak mau mengerti akan kebutuhan anak, dan pendampingan yang sangat dibutuhkan. Melepaskan begitu saja anak dengan bebas mengakses apapun yang mereka butuhkan atau inginkan. Beda generasi membuat anak lebih mudah beradaptasi menggunakan smartphone dengan cepat, sementara banyak orang tua masih gagap dalam menggunakannya. Bagi orangtua, hambatan muncul saat mereka tidak mengerti secara teknis dan kurang literasi media sehingga tidak bisa mengontrol anak dalam mengakses sosial media dan informasi apapun yang didapat. Namun dewasa ini sudah banyak orang tua mulai mau belajar untuk menggunakan smartphone dan menjadikan itu sebagai sebuah kebanggaan karena kemampuan tersebut. Tanpa mengesampingkan peran ayah, namun di Indonesia, pendampingan anak lebih banyak masih dipegang oleh seorang ibu, terutama ibu rumah tangga, 


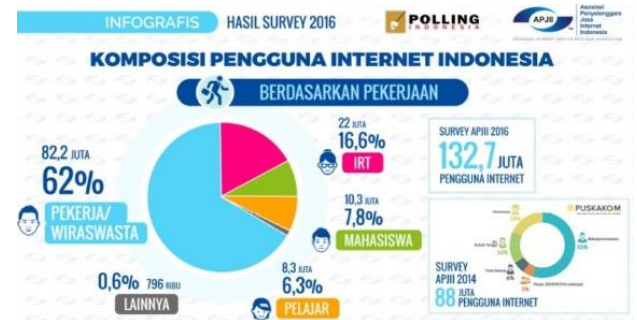

Gambar 2. Data Komposisi Pengguna Internet di Indonesia

Sumber : Asosiasi Penyelenggara Jasa Internet Indonesia.2016

Dilihat dari komposisi pengguna internet Indonesia dari APJII, 2016, setelah pekerja dan wiraswasta yang menggunakan internet secara aktif, di posisi kedua dengan 16, 6\% adalah ibu rumah tangga. Banyak diantara ibu rumah tangga menggunakan internet sebagian besar untuk mengakses media sosial. Selain untuk mengunggah foto diri dan keluarga, banyak ibu rumah tangga menjadikan media sosial akses utama berkomunikasi dengan sesama ibu rumah tangga lain. Misalnya melalui aplikasi whatsapp, mereka dengan mudah akan bertukar informasi seputar harga-harga bahan pokok, kesehatan, kecantikan, tumbuh kembang anak, sampai bergossip yang juga digemari para ibu rumah tangga. Banyak informasi lewat whatsapp yang diterima dan langsung dengan mudah nya disebarluaskan tanpa mereka secara kritis memeriksa kembali kebenaran informasi tersebut. Untuk itu sasaran PKM ini memang mengarah kepada para ibu rumah tangga.

Literasi media penting diberikan kepada Ibu rumah tangga terutama karena perannya besar dalam mendidik putraputrinya di rumah. Jika para ibu rumah tangga tidak memiliki kemampuan untuk secara kritis menganalisa setiap infromasi atau pesan yang diterima lewat media sosial, bagaimana mereka akan mengajari atau mendampingi putra putrinya?
Apalagi dengan adanya revolusi industry 4.0 yang mengedepankan kecerdasaan buatan, maka perlu setiap ibu perlu mendampingi anak-anaknya dengan informasi yang tepat. Mereka perlu menyiapkan anak-anak menghadapi revolusi industry 4.0 agar anak bsia kreatif dan mampu beradaptasi menghadapi tantangan tersebut. Dengan posisinya tersebut, penting bagi ibu rumah tangga tahu mengenai media sosial dan terliterasi karena bisa menyebarluaskan pemahamannya pada anggota keluarga.

Selain itu, ibu rumah tangga yang tidak bekerja memiliki waktu luang yang lebih banyak sehingga ada kemungkinan akses terhadap media sosial lebih banyak dilakukan sehingga merekalah yang pertama kali akan menerima informasi atau pesan. Jika mereka tidak terliterasi dengan baik tentang berita hoax, atau informasi apapun yang juga memicu konflik, maka bisa saja mereka akan langsung menyebarkannya. Sehingga keadaan tersebut justru membuat keberadaan ibu rumah tangga makin dilabeli sebagai pembuat gossip, penyebar hoax. Ini bukan hal yang bisa dibanggakan terutama di mata anak-anak. Jika mereka terliterasi dengan baik, ada kebanggaan bahwa mereka walaupun di rumah tetapi masih lebih pintar, lebih kreatif, dan bukan hanya mengurus dapur dan bergosip saja.

Saat ini ada banyak organisasi yang bisa diikuti oleh para ibu rumah tangga seperti kegiatan PKK atau Posyandu, arisan, senam pagi, dll. Dalam komunitas nya masing-masing maka para ibu rumah tangga yang sudah terliterasi media dengan baik, bisa memperluas dan memperkaya pengalaman di dalam organisasi. Pendidikan Literasi media penting diadakan karena kita perlu mendapatkan informasi yang cukup tentang media, serta mengapa dan bagaimana informasi dikomunikasikan. Masyarakat perlu memiliki kemampuan untuk menilai informasi tersebut bisa 
dipercaya atau tidak. Media sosial merupakan bagian penting yang menjadi satu pengalaman baru bagi masyarakat luas sebagai sarana mendapatkan informasi selain dari media lain seperti koran, tv, radio, dan buku.

\section{METODE}

Metode digunakan dalam PKM ini adalah pelatihan yang meliputi pengajaran dan praktek langsung. Iriantara $(2017$, h. 70$)$ menyebutkan bahwa proses pembelajaran dalam model pelatihan yang dikembangkan Stole (2001) mencakup situasi pembelajaran dengan parameter (1) kepemimpinan, bahwa dalam pengajaran memastikan bahwa setiap materi bisa dimengerti oleh peserta sehingga mereka bisa memiliki dan mengembangkan materi yang diterimanya. Selain itu (2) peran pelatih di dalam pelatihan ini adalah sebagai fasilitator atau mitra pembelajaran yang menempatkan diri dalam kedudukan sejajar dengan peserta. (3) peran peserta adalah menghasilkan pengetahuan atau berbagi pengalaman untuk memperkaya setiap individu di dalam pelatihan ini. Dan (4) sesi fleksibel dan disesuaikan dengan kebutuhan. Walaupun tersedia waktu terbatas setiap sesi nya, tetapi di akhir acara masih diperbolehkan bagi setiap peserta untuk mengajukan pertanyaan. Bahkan para ibu rumah tangga juga berkesempatan berbagi cerita terkait permasalahan yang dihadapi dan saling berbagi solusinya. (5) Penekanan pembelajaran selain sesi teori juga langsung praktek dengan menggunakan gadget masing-masing.(6) fokus pada pembelajaran tentang media literasi.

Dengan demikian, dengan pendekatan bahwa peserta adalah mitra pembelajaran, mendorong peserta untuk saling mengajari satu sama lain. Sesi ini terjadi pada saat sesi praktek langsung, setiap peserta dibagi dalam kelompokkelompok kecil yang masing-masing kelompok didampingi fasilitator (dosen dan mahasiswa). Peserta menjadi lebih nyaman, penyerapan materi pun menjadi seragam sehingga setiap materi yang diberikan bisa dicerna, kemudian diskusi bersama dengan keaktifan setiap peserta memberikan contoh-contoh dari kasus atau permasalahan yang dihadapi.

Sesi pengajaran diisi dengan topik Literasi Media adalah (1) Definisi berita Hoax dan Pentingnya memahami tentang Hoax, (2) Menganalisa berita Hoax di aplikasi Whatsapp dan media sosial lainnya, (3) Dampak berita Hoax, (4) Tips Menghadapi berita Hoax, contoh, dan aplikasinya di media sosial.

Dalam pelaksanaannya, ada beberapa mahasiswa dilibatkan dalam PKM ini. Tujuannya agar mahasiswa pun bisa beradaptasi, mau dengan sabar mengajari orang yang lebih tua dengan tidak melupakan tetap hormat kepada mereka. Demikian juga menjadikan mahasiswa sebagai fasilitator akan membuat seolaholah para ibu belajar dan berbagi Bersama anak-anak mereka. Agar membuat supaya tidak ada jarak selama sesi sehingga setiap peserta bisa dengan nyaman belajar, bercerita, bertanya agar setiap materi dan pesan yang disampaikan bisa terserap dengan baik dan membekas menjadi materi pembelajaran yang bisa mereka bagikan juga di rumah maupun di komunitas lain.

\section{HASIL DAN PEMBAHASAN}

\subsection{Hasil}

Pelatihan Literasi Media Menghadapi Era Industri 4.0 Bagi Ibu Rumah Tangga Di Daerah Tangerang mengambil lokasi di dua tempat. Pemilihan lokasi ditentukan dari lokasi yang paling dekat dengan kampus UPH, dan juga satu lokasi yang pernah menjadi desa binaan UPH. Dipilihlah dua tempat di kelurahan Bencongan Indah, Karawaci dan Mauk, Tangerang. 
Pelatihan pertama berlangsung pada tanggal 12 Juli 2018 bagi Ibu-ibu PKK Kelurahan Bencongan Indah. Dengan memilih tagline 'Pahlawan Anti Hoax', yang bermakna bahwa nantinya sesudah selesai pelatihan maka setiap peserta bisa menjadi Pahlawan anti Hoax baik di rumah maupun di komunitasnya. Mereka bisa mengajari orang lain agar lebih kritis dalam menerima setiap informasi atau pesan yang muncul di media sosial. Target peserta dalam kegiatan ini adalah 25 orang, agar setiap peserta bisa fokus dan proses diskusi bisa berjalan dengan baik. Namun di hari pelaksanaan jumlah peserta bertambah karena banyak yang ingin ikut serta menambah wawasan dalam pembelajaran kali ini. Walaupun banyak diantar mereka yang tidak hadir sampai selesai karena perlu menjemput anak sekolah dll, tetapi acara tetap berjalan dengan baik. Awalnya agak sulit untuk mengumpulkan para ibu dan menyesuaikan waktu di tengah kesibukan mereka di rumah masing-masing. Tetapi karena keinginan untuk belajar dan menambah ilmu, mereka mau meluangkan waktu sejenak agar bisa mendapatkan tambahan wawasan.

Survey awal di lokasi yang sangat dekat dengan kampus UPH. Ada beberapa pilihan lokasi di sekitar kampus UPH, namun karena saat kunjungan ke kelurahan ini, Pak Lurah Hasan Basri sendiri yang meminta agar adanya pelatihan tentang penggunaan media sosial untuk menanggulangi berita hoax. Gayung bersambut karena ini sesuai dengan road map PKM Program Studi Ilmu Komunikasi tentang Literasi Media. Sehingga proses persiapan dengan bantuan aparat setempat dilakukan agar pelaksanaan nya berjalan dengan baik.

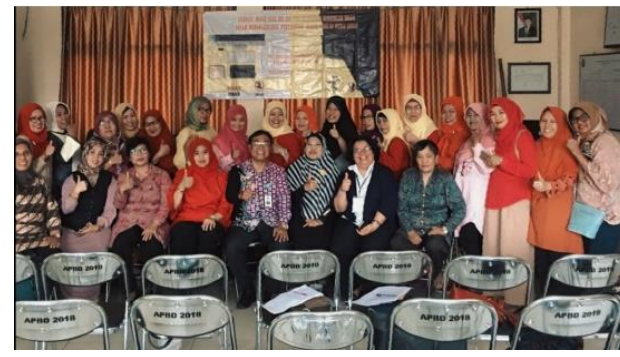

Gambar 3. Foto Bersama peserta usai sesi.

Di hari pelaksanaan PKM, setelah semua peserta hadir, acara diawali dengan doa dan pidato sambutan dari Pak Lurah. Sesudah nya sesi materi yang diawali dengan definisi dari media sosial, bentukbentuk media sosial, dan langsung mengarah utamanya adalah Whatsapp. Para peserta mencatat dan mendengarkan materi dengan cermat.

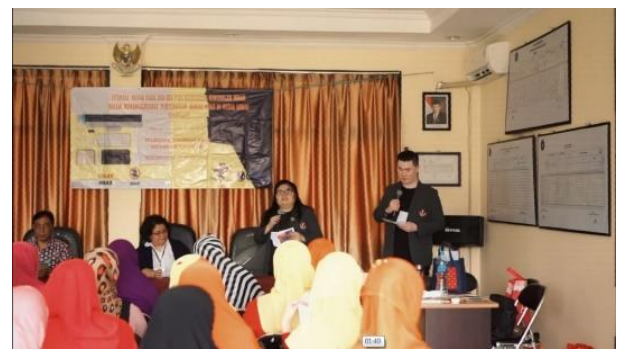

Gambar 4. Sesi tanya jawab

Dan pada saat sesi tanya jawab, banyak hal yang ditanyakan termasuk mengkonfirmasi beberapa pesan yang pernah diterima apakah masuk konten hoax atau bukan. Peserta bahkan menceritakan tentang masalah-masalah yang dihadapi saat harus berhadapan dengan anak, dan segala pertanyaanpertanyaannya. Ada satu ibu yang menanyakan hal yang sangat sederhana sekali namun ini perlu juga dicermati. Ibu itu bertanya 'Apakah sayur kangkong berbahaya bagi kesehatan itu berita hoax atau bukan?. Tentu saja pertanyaan ini disambut oleh tertawa lebar oleh seluruh peserta. Ibu ini menceritakan bahwa 
anaknya tidak suka makan sayuran, terutama kangkung. Suatu hari si anak mengirimkan pesan lewat whatsapp tentang bahaya mengancam dari sayur kangkung, di batangnya banyak telur cacing sehingga tidak diperbolehkan untuk dimakan. Dari pelatihan ini, ibu ini belajar cara membuktikan bahwa berita itu hoax atau tidak yaitu lewat sesi selanjutnya praktek langsung.

Pada sesi kedua, Peserta dibagi ke dalam kelompok-kelompok kecil, dan dibantu dengan para mahasiswa di setiap kelompok ada fasilitator nya. Setiap informasi atau pesan yang diterima lewat media sosial terutama whatsapp, peserta diajari cara mengkonfirmasi dengan melakukan cek ulang mengakses media massa kredibel untuk membuktikan apakah informasi yang diterima tersebut sudah diberitakan juga di media massa atau tidak. Ini adalah salah satu cara pembuktian yang paling mudah. Selain itu di sesi pelatihan ini, setiap peserta juga diajari agar tidak mudah menyebarkan kembali setiap informasi yang didapat. Walaupun konsep berbagi adalah hal baik dalam pandangan agama, tetapi berbagi sesuatu yang belum tentu kebenarannya bukan sesuatu yang baik. Bahkan bisa memicu konflik dan pertentangan yang tidak berkesudahan.

Akhirnya pelatihan dengan durasi 3 jam (180 menit) selesai sudah. Setiap peserta merasa puas, dan bangga karena berhasil mendapatkan wawasan baru sehingga ingin mencoba dan memberitahu anakanak di rumah. Mereka pulang dengan membawa hasil bahwa mereka bisa dan mampu lebih melek media, terliterasi dengan baik dan bisa membagikannya dalam keluarga. Terkesan dengan pelaksanaan kegiatan ini, baik peserta maupun mahasiswa jutru tidak ingin pelatihan ini berhenti begitu saja. Fasilitator dan peserta berinisiatif membuat group whatsapp bersama, dan setiap pertanyaan apapun yang disampaikan, mahasiswa siap membantu dan mencarikan infromasi yang benar.
Group whatsapp ini cukup aktif sampai kurang lebih 3 bulan, tetapi karena kesibukan mahasiswa dalam perkuliahan, pengelolaan group akhirnya diserahkan kepada ibu lurah dan beberapa ibu-ibu yang sudah sangat baik kritis mencermati setiap pesan ini.

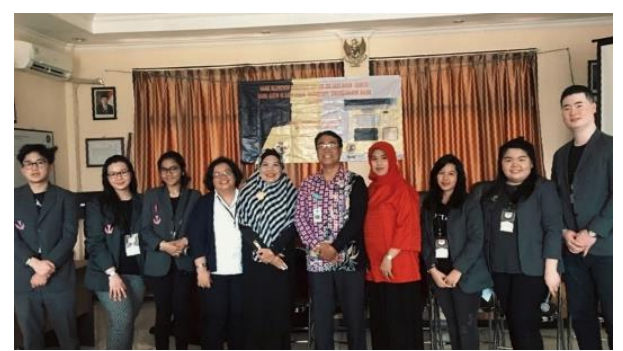

Gambar 5. Foto bersama Lurah Bencongan Indah Bpk. Hasan Basri

Setiap peserta berhasil memahami setiap pesan yang masuk terutama melalui media sosial harus dibaca dengan cermat. Peserta juga mengerti bahwa tidak setiap pesan masuk, tidak setiap informasi yang didapat bisa langsung disebarluaskan. Harus dicek terlebih dahulu, bahkan peserta sampai pada kesimpulan kalau informasi itu tidak penting, tidak merugikan buat diri sendiri, untuk apa disebarluaskan kepada orang lain. Akhir acara ditutup dengan pesan dair Pak Lurah bahwa kegiatan postif seperti PKM ini perlu dilakukan berulang agar bisa memberikan manfaat bagi masyarkat luas.

Pelatihan kedua berlangsung pada tanggal 19 Juli 2018 bagi Ibu rumah tangga dengan anak-anak nya yang bersekolah di SDN 1 Mauk Tangerang. Tema kali ini adalah "Butix" - Ibu anti hoax, ide tema ini jsutru muncul dari salah seorang ibu rumah tangga yang menjadi narasumber saat survey untuk melihat apa yang menjadi kebutuhan peserta. Uniknya permintaan untuk mengadakan pelatihan bagi ibu rumah tangga datang atas inisiatif kepala sekolah SDN 1 Mauk Tangerang. Kegiatan ini dilakukan beberapa minggu setelah mulainya tahun 
ajaran baru. Target ibu rumah tangga ini adalah untuk memisahkan anak-anak yang baru pertama kali masuk sekolah dari orang tuanya. Biasanya anak-anak ini masih menangis, minta ditunggu oleh ibu-ibu mereka sampai sekolah usai. Untuk itu sekolah mendapatkan ide agar ibu-ibu yang menunggu mendapatkan kegiatan positif daripada sekedar dudukduduk ngobrol saja. Selain itu agar anakanak segera mandiri dan tidak perlu ditunggu ibunya.

Pada PKM ini menariknya lagi bahwa banyak diantara ibu-ibu memiliki smartphone tapi sangat gagap akan teknologi yang ada. Mereka bercerita punya group whatsapp antar ibu-ibu arisan, ibu-ibu yg anaknya satu sekolahan. Mereka akan membalas dan menyebarkan informasi benar-benar mengikuti apa yang diminta oleh ibu lain yang sudah tidak gagap teknologi. Ini menajdi sesuatu yang penting membuat mereka mengerti teknologi dan tidak bisa diminta ini itu untuk memanfaatkan teknologi tersebut. Lokasi PKM kali ini lumayan jauh dari kampus UPH, dan membutuhkan waktu sekitar 2 jam an untuk sampai lokasi. Agar sesuai dengan jam dimana anak- anak masuk sekolah maka sesi harus dimulai jam 8 tepat saat ibu-ibu ini menunggu anak-anak nya sampai kelas usai jam 12.

Acara dibuka dengan doa dan sambutan dari pihak sekolah SDN 1 Mauk. Dan sesi dimulai dengan materi singkat tentang bahaya berita hoax dan bagaimana cara menghadapinya. Sesi materi dibuat lebih singkat untuk memperpanjang waktu sesi praktek. Sesi praktek dibuat lebih lama agar bisa mengajari ibu-ibu menggunakan smartphone mereka juga menguji berita hoax tersebut. Pada sesi praktek ini juga terbuka kesempatan bagi para peserta untuk bertanya dan membagikan pengalamannya dalam berhadapan dengan teknologi.

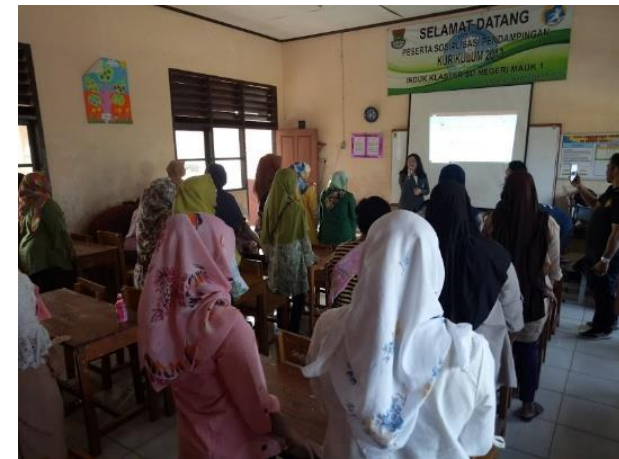

Gambar 6. Acara pembukaan dengan iringan lagu untuk menyemangati peserta.

Ada satu kisah yang dibagikan salah seorang ibu rumah tangga, bahwa ia kerap diejek oleh anaknya saat bertanya tentang cara-cara menggunakan smartphone yang memang belum lama ia miliki. Sang anak tidak sabar mengajari ibunya dan kerap memarahi atas kelambatan sang ibu untuk mengerti teknologi. Sehingga akhirnya ibu ini sudah tidak mau lagi bertanya kepada anaknya. Lain kisah ada seorang ibu rumah tangga yang sudah memiliki anak gadis, dan bercerita sangat sedih karena ia sama sekali tidak tahu kapan pertama kali anak tersebut mendapatkan menstruasi nya. Ibu ini tahu sesudah beberapa bulan si anak mendapatkan nya, dan saat bertanya kepada anak tersebut darimana ia tahu pertama kalinya tentang hal tersebut dan cara mengatasinya. Anak itu menjawab bahwa ia tahu dari teman dan internet, dan meminta ibu ini tidak khawatir karena anak nya sudah mandiri. Ibu ini sedih karena tidak bisa mendampingi anaknya karena ketidakmengertian dan terputusnya komunikasi karena anaknya lebih sibuk dengan hp nya. Beberapa tahun berlalu, ibu ini juga dihadapkan pada kenyataan bahwa dia tidak mengetahui bahwa anaknya mengandung. Dia tahu saat si anak melahirkan cucu pertama baginya tanpa didampingi seorang suami. Ibu ini akhirnya harus mendampingi cucu nya 
bersekolah sementara anaknya bekerja mencari nafkah. Walau sudah berumur, tapi ibu ini tetap berusaha agar mengerti tentang hp dan informasinya agar bisa mendampingi cucunya dengan informasi yang benar. Kisah-kisah serupa banyak ditemui, sehingga memang penting literasi media diberikan kepada ibu-ibu agar mereka ada kebanggaan, kepercayaan diri, dan kemampuan untuk mengajari dan mendampingi anak.

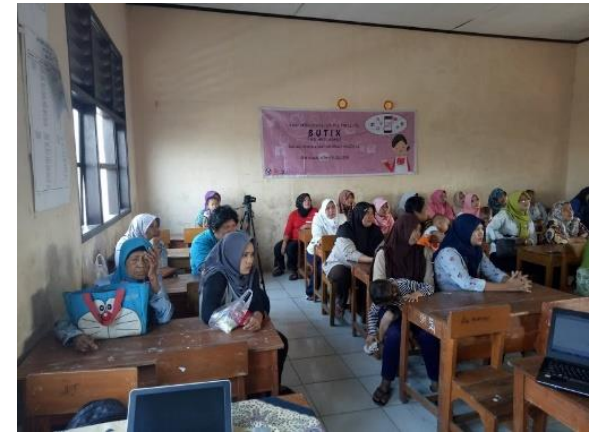

Gambar 7. Sesi Materi

Dari kisah-kisah yang dibagikan oleh para ibu-ibu ini benar-benar menyemangati kami semua untuk bisa mengajari mereka dengan benar menggunakan hp yang mereka miliki. Bukan hanya menggunakannya tetapi juga membuat mereka mampu berpikir kritis agar bisa menyaring informasi apapun yang didapat dan tidak mudah bereaksi terhadap informasi apapun yang didapat. Rasa bahagia terpancar saat bisa membantu ibu tua untuk mengerti bagaimana mengunggah foto lewat media sosial. Selain itu sebetulnya setiap peserta telah terliterasi baca dan menulis, tapi mereka sangat kurang terliterasi media sosial sebagai dampak dari perkembangan teknologi. Waktu yang panjang di sesi praktek tidak membuat setiap peserta bosan, tetapi mereka justru bangga karena belajar sesuatu yang baru.

Hasil dari pembelajaran ini adalah setiap peserta bisa lebih pintar menggunakan smartphone yang mereka miliki. Peserta juga mengerti bahwa tidak setiap pesan atau informasi yang mereka dapatkan dipercaya $100 \%$ kebenarannya. Mereka harus membaca dengan cermat, dan menguji kembali salah satunya lewat media massa. Benarkah informasi tersebut, apakah media massa sudah memberitakannya. Kalau belum berarti tidak terbukti kebenarannya. Setiap peserta juga memahami bahwa ada dampak buruk saat menyebarluaskan informasi atau berita hoax. Salah satunya bisa memicu konflik bahkan konflik dengan tetangga dekat. Peserta juga mengerti bahwa jika tidak ada kepentingannya untuk apa menyebarkan informasi yang mereka pun tidak pahami kepada orang lain. Jika mereka paham akan informasi tersebut atau pesan yang diterima dan sudah dibaca dicek kebenarannya maka mereka baru akan menyebarluaskannya.

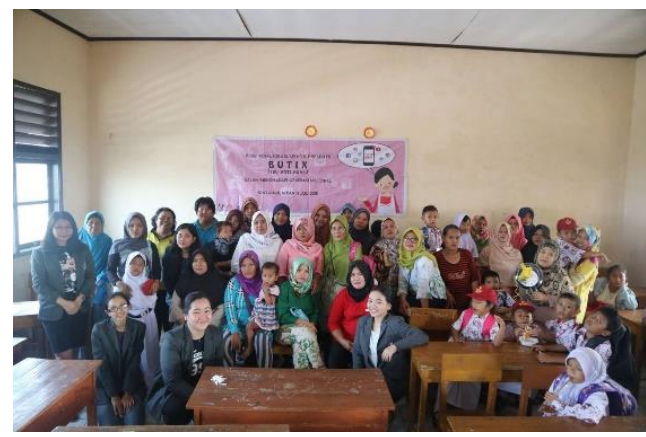

Gambar 8. Foto bersama seluruh peserta

Di akhir acara, setiap peserta merasa senang dan bangga karena belajar sesuatu yang membuat mereka lebih percaya diri. Dan bagi mahasiswa, mereka mendapatkan sebuah pembelajaran bahwa sesuatu yang mereka anggap kecil dan bukan apa-apa bisa memberikan dampak yang besar bagi orang lain dan bisa membekas di ingatan.

Dari kedua pembelajaran yang sudah dilakukan dalam Pkm Pelatihan Literasi Media Menghadapi Era Industri 4.0 Bagi 
Ibu Rumah Tangga Di Daerah Tangerang adalah berhasil membekali para ibu rumah tangga lebih melek media, terutama menggunakan media sosial dengan bijak dan cermat, dan tidak mudah membagikan berita hoax yang diterima. Hasil lainnya adalah mampu mengubah pola piker bahwa sebagai orang tua, setiap ibu rumah tangga punya peran yang sangat penting dalam mendamping anakanak nya termasuk dalam penggunaan teknologi dan media sosial.

\subsection{PEMBAHASAN}

Media merupakan sebuah sarana untuk berkomunikasi (McQuail dalam Nasrullah 2016, 3). Sebagai sarana, perkembangan media mengikuti perkembangan teknologi. Dari buku atau media cetak berkembang ke media elektronik televisi dan radio. Dan dengan semakin berkembangnya teknologi komunikasi maka berkembang media baru yang memudahkan orang untuk berkomunikasi, dan semakin mudah dengan adanya ponsel, sehingga apapun bisa dilakukan melalui perangkat kecil saja. Sementara sosial secara sederhana merujuk pada interaksi sosial atau komunitas dimana orang berinteraksi dalam sebuah masyarakat tertentu. Dengan demikian, media sosial merupakan kumpulan perangkat lunak yang memungkinkan individu maupun komunitas untuk berkumpul, berbagi, berkomunikasi, dan dalam kasus tertentu saling berkolaborasi atau bermain (Boyd dalam Nasrullah, 2016, 11). Media sosial disimpulkan sebagai sebuah perantara saat seseorang perlu berinteraksi, menampilkan diri di hadapan orang lain atau masyarakat luas.

Kebutuhan untuk berinteraksi ini juga dialami oleh ibu-ibu rumah tangga. Pekerjaan mereka di sektor domestik, mengurus rumah tangga, mengurus keluarga, memastikan semuanya di dalam rumah mendapatkan kebutuhannya bukan pekerjaan yang mudah. Mereka pun butuh berinteraksi, mengakses dunia luar, dan itu semua disediakan melalui media sosial. Dengan media sosial, memudahkan setiap ibu rumah tangga untuk berinteraksi dengan keluarga dimana pun mereka berada, dengan teman-teman, dan juga dengan komunitas-komunitas yang membuat mereka tidak terkungkung hanya di rumah saja. Namun keinginan untuk berinteraksi dan berkomunikasi lewat media sosial tidak didukung kemampuan cukup untuk menggunakannya. Masih banyak ibu rumah tangga yang kurang terampil dalam berinteraksi menggunakan media sosial Peruntukannya sebatas hanya untuk berbagi informasi dengan ibu-ibu yang lain, atau update status dan menggunggah foto kegiatan atau Bersama keluarga. Sementara posisi ibu rumah tangga justru menjadi bagian penting dalam pendampingan dan pendidikan anak sejak dari dini dan dari rumah sebelum anak itu mulai bersekolah. Tantanggannya adalah ibu rumah tangga harus memiliki kemampuan daalam memanfaatkan secara kreatif media sosial, juga menggunakannya sebagai media pembelajaran. Selain itu kemampuan untuk secara kritis menerima pesan atau informasi lewat media sosial perlu dipelajari agar mampu mengajari anakanaknya dengan baik untuk memanfaatkan teknologi.

Terry dan Gomez (2011) dalam Hakiki \& Supriyanto (2018, 85) menjabarkan beberapa hambatan yang menyebabkan banyak perempuan di negara-negara berkembang kesulitan untuk memperoleh akses dan memanfaatkan teknologi informasi. Hambatan yang sering dihadapi oleh para perempuan adalah masalah ketersediaan waktu dan biaya, karena peran perempuan terutama di Indonesia adalah sebagai ibu rumah tangga. Peran tersebut membuat sebagian 
besar waktunya dan juga biaya lebih fokus ditujukan untuk mengurus anak dan keluarga. Itu juga salah satu kesulitan saat rencana PKM Literasi Media bagi ibu rumah tangga dilaksanakan. Ketersediaan waktu utama mereka untuk anak-anak dan keluarga sehingga sulit sekali menemukan waktu yang cocok. Yang paling sesuai adalah pagi hari di saat anak-anak sekolah dan sampai siang hari. Pelatihan ini tidak bisa diselenggarakan seharian, sementara materi perlu disampaikan secermat mungkin. Akhirnya untuk mengatasi hal tersebut, literasi juga dijalankan memanfaatkan media sosial whatsapp dengan membangun komunitas atau group bersama sebagai forum berbagi.

Para ibu rumah tangga dengan keterbatasan dan kelebihan yang juga mereka miliki, perlu diberikan kemampuan literasi media. Perkembangan media dan teknologi tersebut melahirkan tantangan yang menuntut manusia memiliki kemampuan literasi lain selain membaca dan menulis. Varis (1997) dalam Iriantara $(2017,5)$ menyebutkan bahwa literasi tidak hanya dihubungan dengan membaca dan menulis tetapi sudah diperluas seiring dengan perkembangan komputerisasi. Teks bukan sekedar tulisan tetapi juga teks dalam bentuk produksi audiovisual, karena produk yang dihasilkan juga merupakan penyampaian pesan. Literasi dibutuhkan seseorang agar memiliki kemampuan untuk berkomunikasi dengan orang lain. Jadi agar setiap ibu rumah tangga bisa memiliki kemampuan berkomunikasi dengan baik melalui media sosial maka perlu terliterasi media dengan baik. Media sosial dengan segala kemudahan, keluasan inforamsi yang ditawarkan harus dipelajari dengan baik. Karena keberadaan media sosial ada hasil dari perilaku sosial adanya keinginan berinteraksi dengan banyak orang dengan mudah, memperluas interaksi dengan siapa saja.
Perilaku sosial merupakan timbal balik dari interaksi simbolik sehingga dapat disimpulkan media sosial dilihat dari perkembangan bagaimana hubungan individu dengan perangkat media. Menurut Fuschs (2017, 34 - 37) menyebutkan bahwa karakteristik kerja komputer dalam web 1.0 berdasarkan pengenalan individu dengan individu lain (human cognition) yang berada dalam sebuah system jaringan. Pada Web 2.0 berdasarkan bagaimana individu berkomunikasi (human communication) dalam jaringan antar individu. Pada Web 3.0 karakteristik teknologi dan relasi yang terjadi terlihat dari bagaimana manusia (users) bekerja sama (human cooperation). Dan dalam revolusi industry 4.0 diwarnai dengan kecerdasan buatan (artificial Intellegence), era super komputer yang berdampak pada ekonomi, industri, pemerintahan, dan politik. Dengan perkembangan tersebut, tentu nya membawa pengaruh pada perkembangan media sosial sebagai salah satu penyebar informasi. Kemudahan yang ditawarkan bukan lagi lewat kemampuan kita berinteraksi dengan orang atau individu, tetapi bagaimana setiap perangkat canggih akan makin mempermudah kita dalam berinteraksi. Tuntutannya adalah kemampuan dalam beradaptasi dengan teknologi sehingga kita bisa memanfaatkannya sebaik mungkin, kreativitas yang tinggi dituntut agar bisa beradaptasi.

Perkembangan teknologi yang semakin ramah, semakin mudah dan efisien juga memberikan dampak bagi meningkatnya kepercayaan diri para ibu rumah tangga sebagai perempuan yang mau mengikuti perkembangan teknologi. Banyak ibu rumah tangga sangat menguasai penggunakan ponsel yang semakin berbiaya murah dan ringan. Bahkan ponsel menjadi bagian dari trend sehingga dengan tetap mengikuti teknologinya, membuat kebanggan tersendiri bagi para 
ibu rumah tangga. Hakiki \& Supriyanto (2018, 90) menyebutkan bahwa perkembangan teknologi informasi menjadi bagian dari gaya hidup bagi perempuan di Indonesia. Keterlibatan perempuan dalam mengakses media sosial merupakan bagian dari pencitraan diri. Keterlibatan ini membuat para perempuan, terutama ibu rumah tangga yang cenderung dilabeli tertinggal, lamban, kurang update (kudet), mendapatkan pengakuan. Pengakuan ini didapat dari teman-teman, dan keluarga terutama anak-anak yang sangat tergantung dari keberadaan ibu.

Ketergantungan yang tinggi atas peran ibu di dalam rumah tangga membuat keberadaannya membawa pengaruh bagi keluarga terutama anak-anak. Kemampuan mengakses media sosial sebagai pencitraan dan kebutuhan akan pengakuan bukan lagi hal yang utama dalam menghadapi revolusi industri 4.0 saat ini. Ibu rumah tangga juga harus mampu menjadi agen perubahan untuk bisa menyiapkan anak-anaknya sedari dini untuk kritis dan kreatif memeriksa isi, pesan, dan informasi lewat media sosial. Hal ini untuk menumbuhkan kreativitas dalam diri anak sejak dini untuk memanfaatkan teknologi dan beradaptasi dengan bijak.

Banyak cara bisa dilakukan untuk terliterasi media sosial dengan baik. Center for Media Literacy seperti dikutip Iriantara $(2017,152)$ menyebutkan bahwa untuk memeriksa isi media, termasuk media sosial ada beberapa pertanyaan yang bisa diajukan. (1) Siapa yang membuat pesan. Terkadang pada saat kita menerima pesan dari media sosial, misalnya pesan dari WA tentu saja yang mengirim langsung ke kita lah sebagai sumbernya. Pesan WA juga dikirim pada group-group WA yang setiap anggota nya bisa menshare kan kembali. Sulit untuk melacak siapa sumber pertama dari pesan tersebut, dan selalu kita abaikan. Setiap ibu rumah tangga diajarkan jeli untuk meneliti kembali pesan diterima dari siapa sumbernya, kredibilitas sumber penting sekali. (2) teknik persuasi seperti apa yang digunakan untuk menarik perhatian. Terkadang saat menerima pesan lewat media sosial, kita hanya membaca sekilas jika pesan itu lumayan panjang. Biasanya huruf besar, kata-kata bombastik, warna yang mencolok akan lebih menarik perhatian. Demikian juga para ibu rumah tangga harus belajar mengamati dan mau membaca dengan seksama setiap pesan yang masuk agar bisa menganalisa lebih lanjut kebenaran dari setiap pesan yang diterima lewat media sosial. (3) Bagaimana orang yang berbeda memahami pesan tersebut secara berbeda pula? Pesan yang masuk lewat media sosial apapun yang kita gunakan tidak serta merta menjadi pusat perhatian kita. Setiap orang pasti berbeda-beda dalam merespon setiap pesan yang diterima. Demikian juga para ibu rumah tangga juga mengerti bahwa ada pesanpesan yang menarik perhatian tentang isuisu kesehatan, kecantikan, makanan, atau hal-hal yang dekat dengan keseharian mereka. Ini juga terkait dengan point no (4) adanya nilai-nilai, gaya hidup, sudut pandang apa yang disajikan dalam pesan tersebut. Ini penting dipahami sehingga memunculkan kemudian point nomor (5) mengapa pesan tersebut dikirimkan. Seseorang mengirimkan pesan pasti memiliki tujuan tertentu, dan ini perlu dianalisa secara kritis dari setiap pesan yang disampaikan. Jika kelima hal tersebut di atas dijadikan pedoman dalam menganalisa setiap pesan yang diterima lewat media sosial, membuat kita lebih kritis dalam menerima setiap pesan dan tidak dengan mudah mengirimkan kembali ke orang lain. Kita juga tidak mudah terpapar dengan berita hoax.

Perkembangan teknologi informasi memberikan pengaruh bagi siapa saja. Kemudahan yang ditawarkan, luasnya interaksi dan komunikasi yang didapat 
sangat menarik untuk diadaptasi dalam kehidupan sebagai ibu rumah tangga. Namun dibutuhkan pendidikan yang membentuk wawasan dan pengetahuan lewat literasi media bagi para ibu rumah tangga. Hal ini bisa menjadi modal untuk mempersiapkan generasi muda, anakanak yang cerdas, bermoral, berkualitas dengan daya saing yang tinggi. Di era ini, setiap manusia harus bisa mengikuti perkembangannya, terutama bagi generasi muda. Perkembangan revolusi industri 4.0 harus dimanfaatkan dengan baik. Generasi muda perlu mendapatkan pendampingan, dan tuntutan terhadap peran seorang ibu menjadi besar. Dan seorang ibu rumah tangga pun perlu belajar sepanjang waktu dan tidak ada hentinya agar semakin menjadi perempuan yang melek media, terliterasi dengan baik bisa mendampingi dan mendidik generasi masa depan menghadapi arus informasi dalam era revolusi industri 4.0.

\section{KESIMPULAN}

Perkembangan teknologi informasi dirasakan semua orang termasuk ibu rumah tangga yang bekerja pada sektor domestik. Peran ibu rumah tangga yang fokus hanya mengurusi keluarga membuat ada kecenderungan anggapan lambat serta gagap mengikuti perkembangan teknologi informasi. Justru karena kemudahan yang ditawarkan oleh perkembangan teknologi, banyak perempuan mudah untuk mengikutinya. Banyak ibu rumah tangga yang memiliki teknologi seluler dalam genggamannya, memanfaatkannya sebisa dan sepengetahuannya. Literasi media menjadi bagian penting untuk membuat para ibu rumah tangga mengenal teknologi yang digunakan, pemanfaatannya, terutama saat menggunakan media sosial. Literasi media membuat para ibu rumah tangga mengerti dan menggunakan media sosial secara tepat, cermat, bijak.
Pendidikan menjadi bagian penting dalam perkembangan individu, bukan hanya secara pribadi tetapi juga dalam kerangka kepentingan bagi perkembangan bangsa. Ibu rumah tangga pun perlu mendapatkan pendidikan, pelatihan -pelatihan agar pemberdayaannya sebagai agen pendidik untuk mempersiapkan generasi muda dalam menghadapi revolusi industry 4.0.

Dari PKM yang telah terselenggara maka salah satu saran adalah (1) Kegiatan PKM literasi media ini bisa dilanjutkan agar semakin banyak ibu rumah tangga yang melek media, bisa mengaplikasikan apa yang didapat dan bisa kritis dalam berkomunikasi dan menerima informasi lewat media sosial. Selain itu (2) Kegiatan PKM ini bukan hanya mengarahkan ibu rumah tangga untuk kritis, terliterasi dengan baik dalam menggunakan media sosial sehingga bisa mengarahkan anak-anaknya menjadi manusia kreatif, tetapi dikembangkan juga untuk anak-anaknya generasi muda yang akan berhadapan langsung di industri dengan revolusi 4.0.

Yang terakhir adalah agar (3) kegiatan PKM ini bisa dikembangkan dalam bentuk kerjasama dengan dinas terkait agar dukungan dari pemerintah bisa menjaga luaran yang sudah ada dari PKM masih tetap aktif.

\section{UCAPAN TERIMA KASIH}

Terimakasih yang utama bagi Tuhan yang telah memberikan arahan, tuntunan, ide, kemampuan untuk melaksanakan PKM ini dengan baik. Selain itu, ucapan terimakasih disampaikan kepada :

1. Ibu- ibu PKK Kelurahan Bencongan Indah atas kerjasama, kehadirannya, dan keceriaan yang dibagikan selama pelaksanaan PKM.

2. Ibu- ibu Rumah Tangga, juga ibu dari anak- anak SDN 1 Mauk Tangerang, terima kasih atas 
kehadirannya, cerita-cerita lucu, dan masakannya, yang menjadi kenangan tersendiri selama pelaksanaan PKM.

3. Bpk. Nuryadi, Guru di SDN 1 Mauk Tangerang yang telah menyediakan waktu dan pikiran sehingga PKM bisa terselenggara dengan baik, juga buat bapak Kepala Sekolah SDN 1 Mauk dan Bapak Ibu Guru serta seluruh keluarga besar SDN 1 Mauk yang berkenan membantu, meminjamkan satu kelasnya, menyediakan sound system, dll sehingga acara berjalan dengan baik.

4. Bpk. Hasan Basri, Lurah Bencongan Indah, beserta seluruh staff di Kelurahan Bencongan Indah dengan kerjasama dan penerimaan yang sangat baik sekali.

5. Untuk mahasiswa yang telah bekerja keras, Hanna, Isabella, Ivone, Yosefa atas kerja keras, bangun paginya, kelaparannya, tetap tersenyum padahal pembicara utama bpk Sigit Pamungkas berhalangan hadir karena kedukaan, bisa diajak kerja cepat maneuver bersama ibu Agustin Diana. Juga untuk Desy, Glen, Jessica, Lidia, Louise, Meliana, Stefano, atas kerja keras termasuk dalam mencari dana sampai rela jualan tissue dari mall ke mall agar acara bisa berjalan dengan baik dari awal sampai terakhir. Tim yang sangat kompak sekali.
6. Universitas Pelita Harapan terutama LPPM, Dekan FISIP Edwin Tambunan, Kaprodi Ilmu Komunikasi Marsefio Luhukay, seluruh rekan dosen dan administrasi yang membantu kami dalam melaksanakan PKM ini.

\section{DAFTAR PUSTAKA}

Asosiasi Pengguna Jasa Internet Indonesia (2016). Penetrasi dan Perilaku Pengguna Internet Indonesia, Survey 2016. Diakses pada 10 September 2019.

Di Era Revolusi Industri 4.0. Institut Teknologi Surabaya. Diakses pada 10 September 2019

Fuchs, Christian. (2017). Social Media. A Critical Introduction. $2^{\text {nd }}$ Edition. Sage. USA.

Global Digital Report (2019). We are social.com. diakses pada 10 September 2019.

Hakiki, Gaib. Sugeng Supriyanto. (2018). Profil Perempuan Indonesia 2018. Kementerian Pemberdayaan Perempuan dan Perlindungan Anak. Jakarta.

Iriantara, Yosal. (2017). Literasi Media: Apa, Mengapa, Dan Bagaimana.

Simbiosa Rekatama Media. Jakarta.

Suarmini, Ni Wayan. Siti Zahrok, Dyah Satya Yoga Agustin. Peluang Dan Tantangan Peran Perempuan

Widiyasutiti, Inasari. Tipe Mediasi Ibu Rumah Tangga Terhadap Keselamatan Berinternet Anak Dan Remaja. Jurnal Informasi Volume 47 No. 2. Desember 2017 